onnouncing a

new quarterly journal ...

Princeton University Press

P. O. Box 231

Princeton, N.J. 08540
Philosophy \& Public Atfairs is designed to fill the need for o periodical in which philosophers with different viewpoints and philosophically inclined writers from various disciplines-including low, political science, economics, and sociology-can bring their distinctive methods to bear on problems that concern everyone. Advisory editors are Stuart Hampshire and John Rowls; the editor is Marshall Cohen; and associate editors are Thomas Nogel and Thomos Scanlon.

$\$ 7.50$ a year

$\$ 12.50$ two years

$\$ 17.00$ three years

$\$ 10.00$ a year for institutions

$\$ 2.50$ single issues

$\$ .75$ handling charge on foreign orders

\title{
PHILOSOPHY
}

The Journal of the Royal Institute of Philosophy

Edited by H. B. Acton. Assisted by S. C. Brown.

JANUARY, 1972

Vol. XLVII, No. 179

I Language, Meaning and God.

D. M. MacKay

II Truth and the "Religious Language-game". Patrick Sherry

III Games, Families, The Public, and Religion. F. Gerald Downing

IV Utilitarianism and the Morality of Killing.

R. Stephen Talmage

$\mathrm{V}$ DISCUSSIONS

Armchair Cosmology

$$
\text { W. H. Newton-Smith }
$$

A Priori Knowledge and Cosmology H. W. Boyce

The Ethological Fallacy: A Note in Reply to Mr. Meynell R. K. Jones

VI REVIEW ARTICLE

On Reading Bentham

David Lyons

VII NEW BOOKS

VIII NOTES AND NOTICES

\section{Published Quarterly}

Price $£ 1$

\section{Macmillan Journals Ltd., London}

Members of the Royal Institute of Philosonhy (14 Gordon Square Iondon, WC1 $\mathrm{H}$ OAG) receive the Journal without charge by virtue of their subscription of. 2.50 per annum. 


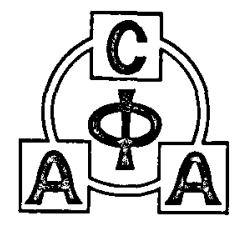

\section{THE NEW SCHOLASTICISM}

A Quarterly Journal of Philosophy

Each issue includes extensive research articles, book reviews, and a chronicle of items of national and international philosophical interest.

Subscriptions: $\$ 8.00$

American Catholic Philosophical Association

The Catholic University of America

Washington, D.C. 20017, U.S.A.

\section{Zeitschrift für allgemeine Wissenschaftstheorie}

Journal for General Philosophy of Science

Edited by ALWIN DIEMER, LUTZ GELDSETZER, GERT KÖNIG

Per year 2 issues of 160 pp. each. Annual subscription DM 56,-

From the contents of vol. II/1, 1971

GERHARD FREY, Möglichkeiten und Grenzen einer wissenschaftlichen Philosophie

BELA JUHOS, Logischer Positivismus und Empirismus

HANS-PETER LORENZEN, Bemerkung über eine Möglichkeit der

Definierbarkeit von Wahrheit

EDGAR MORSCHER, U̇ber Positive, Komparative und Superlative HERBERT SCHNÄDELBACH, Dispositionsbegriffe der Erkenntnistheorie

Berichte

HIROSHI NAGAI, Recent Trends in Japanese Research on the Philosopy of Science

GERHARD RADNITZKY, Wissenschaftstheorie als Forschungsforschung

FRANZ STEINER VERLAG GMBH

WIESBADEN, GERMANY 


\section{The Southern Journal \\ of Philosophy}

\section{Volume 9-Fall, 1971-No. 3}

\section{ARTICLES}

The Theory of Recollection in Plato's Meno

Daniel E. Anderson

Meaning and Proper Names

L. S. Carrier

Modal Disproofs and Proofs for God

Bowman L. Clarke

Is There Meaning Independent of Force?

D. S. Clarke, Jr.

An Approach to Heidegger's Way of Philosophizing

Is Knowledge Definable?

Bernard P. Dauenhauer

Various Interpretations of Kierkegaard's Paradox:

An Appraisal and Suggestion Timothy Tian-Min Lin

The Philosophical Psychology of William James

C. I. Lewis and the Sense of Sense Meaning

Andrew J. Reck

Sandra B. Rosenthal

The Universalistic Evolution of Charles Sanders Peirce

W. H. Werkmeister

THE SOUTHERN JOURNAL OF PHILOSOPHY is published quarterly by the Department of Philosophy, Memphis State University, Memphis, Tenn. 38111. Editors: Carroll R. Bowman and Gene G. James

Annual subscription rate to individuals, $\$ 6.00$; for institutions, $\$ 8.00$; for students, $\$ 4.00$; prices for single copies available on request.

\section{JBSP: Journal of \\ The British Society for Phenomenology \\ Editor: Wolfe Mays (University of Manchester)}

Volume 3

January, 1972

Number 1

\section{FRENCH AND GERMAN PHILOSOPHY TODAY}

\section{PROPOSED CONTENTS:}

Editorial

French Philosophy over the Last Decade by Suzanne Gillet-Stern The German Philosophical Scene by Klaus Hartmann

The World as Noema and as Referent by Guido Kung

Saying and Showing in Heidegger and Wittgenstein:
I Peter McCormick
II Eva Schaper
III J. M. Heaton

Wittgenstein and the Case for Structuralism by Philip Pettit

Sarte and the Phenomenology of the Simagination by Ronald Grimsley Discussion: Husserl and Hodgson,

Some Historical Remarks by Karl Schuhmann Reviews

Published three times per year in January, May and October by HAIGH \& HOCHLAND LTD. 399 Oxford Road, Manchester 13, England Subscription Rates: $\$ 10.50$ (£3.50) per annum, postage free 
Process Studies focuses on the thought of Alfred North Whitehead, related philosophers, and other process thinkers; develops the wider implications of process thought; and encourages readers' discussion on materials published.

\section{Contents include:}

Major articles on Whiteheadian and other process philosophy and its implications for epistemology, metaphysics, theology, ethics, aesthetics, mathematics, physics, biology, cosmology, history of religions, social science, and literary criticism.

Thorough reviews of relevant books.

Resumes of relevant articles published elsewhere.

Detailed bibliography of Whitehead in an early issue.

\begin{tabular}{|c|c|}
\hline ution & duals \\
\hline $\begin{array}{rrr}1 & \text { Yr. ....... } & \$ 7 \\
2 & \text { Yr. ...... } & 12 \\
3 \text { Yr. ....... } & 17\end{array}$ & $\begin{array}{rrr}1 & \text { Yr. ...... } & \$ 6 \\
2 & 6 r . \ldots . . & 10 \\
3 & \text { Yr. ....... } & 14\end{array}$ \\
\hline
\end{tabular}

ADDRESSES

Subscription Orders and Business Correspondence PROCESS STUDIES

1325 N. College Ave.

Claremont, Calif. $\mathbf{9 1 7 1 1}$

Manuscripts

LEWIS S. FORD

246 Sparks Building

Pennsylvania State University

University Park, Pa. 16802

\section{ARTICLES APPEARING IN EARLY ISSUES INCLUDE:}

"Dialectical v. Di-Polar Theology"

"Non-Being and Hartshorne's Concept of God"

"Could There Have Been Nothing? A Reply"

"Whitehead on the Metaphysical Employment of Language"

"The Relatedness of Eternal Objects in Whitehead's Process and Reality"

"A Rejoinder to Justus Buchler"

"Whitehead and the Nature of Mathematical Truth"

"The Whitehead Without God' Debate"

Thomas J. J. Altizer Houston Craighead Charles Hartshorne

Donald A. Crosby John W. Lango Ivor Leclerc

Ann P Lowry Donald W. Sherburne and John B. Cobb, Jr.

\section{International \\ Vol. XII-No. 1-March, 1972 \\ Articles \\ Philosophical Quarterly}

Self and Other: The Radical

A priori

KENNETH T. GALLAGHER

Language in Husserl and

the Neo-Humboldtians

HERMAN PARRET

Dwelling in the World through Language DALE W. CANNON

Heidegger's Criticism of "Entitative Metaphisics" DONALD A. CRESS

in His Later Works

The Influence of Gassendi on

Locke's Hedonism

EDWARD A. DRISCOLL

Contemporary Currents

'Depth Grammar' as a Methodological Concept

in Philosophy

G. BENJAMIN OLIVER

Feature Book Review

Gerard Radnitzky, Contemporary Schools

of Metascience

ROBERT NEVILLE

FORDHAM UNIVERSITY

Bronx, N.Y. 10458

$\$ 8$ a year 